\title{
ANALISIS MODEL PREDIKSI KEBANGKRUTAN PADA PERUSAHAAN PERBANKAN YANG GO-PUBLIC DI BURSA EFEK INDONESIA (PT. BEI)
}

\author{
Oleh: \\ Febry Sanur Saputra \\ Staff PT. Bank Negara Indonesia (Persero) Tbk, Bima NTB \\ E-mail/No. Hp: - /037442232
}

\begin{abstract}
Purpose of this research is applying of prediction model of company bankruptcy of banking which go-public in Indonesia based on the company financial statements. Model who applied is Model Z-Altman applied to predict company's finance performance. This model applies combination of standard ratios, which are circulating capital ratio, profit ratio arrested, profit ratio before interest and tax, equity market value ratio and sale ratio. In this research applied also financial ratios CAMEL as comparator, with level of health that has been specified Bank Indonesia. Sampling method in this research is method purposive sampling, consisted of eight banking company in Indonesia Stock Exchange/Bursa Efek Indonesia (BEI) and included in catalog 10 banks with the biggest leg asset until end of time line 2008. Result of research indicates that from model Altman and CAMEL leaves for back. Model Altman predicts that all sample bank stays at potential condition gone broke, while CAMEL predicts sample bank to stay at healthy condition.
\end{abstract}

Keywords: discriminate z-altman, camel, financial ratios, bankruptcy

\section{PENDAHULUAN}

Seiring dengan krisis multi dimensi yang menimpa Indonesia sejak pertengahan tahun 1997 yang dimulai dengan merosotnya nilai rupiah terhadap dollar Amerika Serikat telah menghancurkan struktur ekonomi termasuk sektor perbankan. Krisis moneter yang terus menerus mengakibatkan krisis kepercayaan, akibatnya banyak bank mengalami masalah yang sama karena kredit macet.

Krugman (1999) mendukung pentingnya persoalan corporate failure yang mengulas mengenai global financial downturns dan memasukkan teori balance sheet fundamentals sebagai signal dari krisis yang akan terjadi. Walaupun penelitian corporate failure telah banyak dilakukan, tampaknya penelitian mengenai hal ini akan terus berlanjut karena perkembangan dunia usaha yang begitu cepat.

Menurut Setyorini dan Ardiati (2006), kebangkrutan perusahaan dapat dilihat dan diukur melalui laporan keuangan, dengan cara menganalisis laporan keuangan. Analisis laporan keuangan merupakan alat yang sangat penting untuk memperoleh informasi yang berkaitan dengan kondisi keuangan perusahaan serta hasil-hasil yang telah dicapai sehubungan dengan pemilihan strategi perusahaan. Dengan melakukan analisis laporan keuangan perusahaan, maka pimpinan perusahaan dapat mengetahui keadaan serta perkembangan finansial perusahaan serta hasil-hasil yang dicapai, diwaktu lampau dan diwaktu yang sedang berjalan. Selain itu 
dengan melakukan analisis keuangan diwaktu lampau, maka dapat diketahui kelemahan-kelemahan perusahaan serta hasil-hasil yang dianggap telah cukup baik, dan mengetahui potensi kebangkrutan perusahaan tersebut.

Kreditur dan investor tentu tidak menginginkan perusahaan perbankan di mana kreditur dan investor menyimpan atau menanamkan uangnya mengalami kebangkrutan, dilikuidasi atau ditutup. Sedangkan calon kreditur dan calon investor, akan mencari informasi agar tidak menyimpan atau menanamkan uangnya pada perusahaan perbankan yang berpotensi bangkrut, likuidasi atau ditutup. Untuk itu mereka memerlukan informasi mengenai indikasi-indikasi penting agar mereka tidak mengalami kerugian.

Adanya kondisi tersebut menyebabkan para kreditur dan investor merasa khawatir jika perusahaan mengalami kesulitan keuangan (financial distress) yang bisa mengarah pada kebangkrutan. Oleh sebab itu diperlukan pengusaha yang tangguh yang mampu meningkatkan kinerja perusahaan serta mempunyai pemikiran dan tindakan kreatif untuk menjadikan perusahaan unggul dan kompetitif pada saat perusahaan lain mengalami kegagalan serta mampu mengembangkan kemampuannya untuk mengikuti perubahan terus menerus dalam era globalisasi agar perusahaan tetap eksis di masa mendatang.

Indira dan Dadang (1998) dalam D. Suryandari beramsumsi suatu sistem perbankan dikatakan sehat apabila bankbank dalam sistem tersebut berada dalam kondisi solvent. Suatu bank dikatakan solvent, apabila nilai asset lebih besar dari jumlah kewajiban yang harus ditanggung baik dari deposan maupun kreditur.

Analisis Altman dan CAMEL merupakan merupakan dua model yang dapat memprediksikan kondisi keuangan perusahaan perbankan. Analisis Z-score atau diskriminan Altman merupakan alat yang di temukan Altman pada tahun 1986 dapat digunakan untuk mengetahui posisi perusahaan pada kondisi bangkrut, rawan bangkrut atau tidak bangkrut. Model kebangkrutan yang dikembangkan oleh Edward Altman seorang Professor of Finance dari New York University School of Bussines yang dikenal dengan Altman Z-score. Model ini menggunakan analisis keuangan yang dibuat dengan mengkombinasikan lima rasio keuangan yang berbeda-beda (Rasio Modal Kerja/Total Aktiva, Laba Ditahan/Total Aktiva, Earning Before Income and Tax/Total Aktiva, Nilai Pasar Modal/Nilai Buku Hutang, Penjualan/Total Aktiva) untuk menentukan potensi atau kemungkinan bangkrutnya sebuah perusahaan dengan penyesuaian dari nilai Z-nya, berdasarkan nilai titik cut-off yang ditetapkan Altman. Sedangkan CAMEL terdiri lima kriteria yaitu modal, aktiva, manajemen, pendapatan dan likuiditas.

Disamping itu, untuk mempertajam analisis guna memprediksi kesulitan keuangan dan kebangkrutan perusahaan perbankan akan dikaitkan pula nilai Z-Score yang diperoleh dengan kriteria CAMEL sebagai ukuran tingkat kesehatan bank. Dengan demikian pihak manajemen dapat melakukan langkah-langkah perbaikan kinerja dan mengetahui cara penanggulangannya. Dari paparan latar belakang di atas dapat diambil rumusan masalah yang nantinya akan dibahas lebih lanjut dalam penelitian yaitu 1) Apakah tingkat kebangkrutan pada perusahaan perbankan yang Go-Public di Bursa Efek Indonesia dapat diprediksi dengan Model Altman. 2)Bagaimana analisis Model Altman jika dibandinkan dengan Model CAMEL. 


\section{TINJAUAN PUSTAKA}

Beaver (1966) melakukan penelitian untuk memprediksi kegagalan suatu usaha dengan menggunakan enam kelompok rasio keuangan yang dianalisa dengan menggunakan metode univariat. Tiap rasio dilihat kekuatan prediksinya. Rasio keuangan yang digunakan adalah cash flow ratios, net income ratios, debt total assets ratios, liquid assets to total assets, liquid assets to current debt ratio dan turn over ratios. Penelitian Beaver mengambil sampel 79 perusahaan yang gagal dan 79 yang tidak gagal pada periode 1954-1964. Hasilnya menunjukan bahwa cash flow rasio (cash flow to total debt) merupakan merupakan predictor yang paling kuat dengan ketetapan prediksi $78 \%$ pada tahun kelima sebelum kebangkrutan dan 87\% setahun sebelum kebangkrutan.

Suparti (1993-2000) melakukan penelitian dengan mengambil data sekunder berupa laporan keuangan dari 16 perusahaan perbankan yang kemudian dihitung menggunakan Model Altman, yaitu Z-Score yang merupakan gabungan dari 5 rasio. Adapun 5 rasio tersebut yaitu rasio modal kerja terhadap total aktiva (X1), rasio laba ditahan terhadap total aktiva (X2), rasio laba sebelum bunga dan pajak terhadap total aktiva (X3), rasio nilai pasar modal terhadap total hutang (X4), dan rasio penjualan terhadap total aktiva (X5). Apabila nilai $Z>2,90$ perusahaan diindikasikan tidak bangkrut, nilai $\mathrm{Z}<$ 1,20 maka perusahaan diindikasikan bangkrut, dan apabila terletak antara $1,20<Z<2,90$ perushaan tidak terdeteksi apakah akan bangkrut atau tidak. Hasil analisis 16 bank (Panin Bank, Lippo Bank, Interpack Bank, Bank NISP, Bank Niaga, Bank Danamon, BII, Bank Bali, Bank Papan Sejahtera, United City Bank, Bank Tiara Asia, Bank Universal, Bank PDFCI, Tamara Bank, Bank Palapa (Duta), dan
Bank Rama) menunjukan nilai variabel Z-Score dibawah standar (1,20) dan 16 bank tersebut diprediksikan bangkrut.

Altman (1968) dalam Mahfoedz (1999) menggunakan sampel sebanyak 66 perusahaan yang terdiri 33 perusahaan bangkrut dan 33 perusahaan tidak bangkrut. Altman menggunakan Multivariate Discriminant Analysis dalam menguji manfaat lima rasio keuangan dalam memprediksi kebangkrutan. Studi lain dilakukan oleh Altman (1968). Dia menemukan ada lima rasio keuangan yang dapat digunakan untuk mendeteksi perusahaan dua tahun sebelum perusahaan tersebut bangkrut. Kelima rasio tersebut terdri dari: cash flow to total debt, net income to total asset, total debt to total asset, working capital to total asset dan current rasio. Altman juga menemukan bahwa rasio-rasio tertentu, terutama likuiditas dan leverage, memberikan sumbangan terbesar dalam rangka mendeteksi dan memprediksi kebangkrutan perusahaan. Model Altman ini dikenal dengan Z-score yaitu skor yang ditentukan dari hitungan standart kali nisbah-nisbah keuangan yang menunjukkan tingkat kemungkinan kebangkrutan perusahaan.

Wilopo (2001) meneliti terkait dengan prediksi kebangkrutan bank di Indonesia. Sampel dalam penelitian ini dilakukan secara cluster yaitu 235 bank pada akhir tahun 1996 dibagi menjadi 16 bank terlikuidasi dan 219 bank yang tidak dilikuidasi. Selanjutnya diambil $40 \%$ sebagai sampel estimasi, terdiri atas 7 bank yang terlikuidasi dan 87 bank yang tidak dilikuidasi. Kemudian 215 bank pada akhir tahun 1997 yang terdiri atas 38 bank yang terlikuidasi dan 177 bank pada tahun 1999 yang tidak dilikuidasi. Selanjutnya diambil $40 \%$ sebagai sampel validasi yang terdiri atas 16 bank terlikuidasi dan 70 bank yang tidak dilikuidasi. Variabel yang 
digunakan dalam penelitian ini untuk memprediksikan kebangkrutan bank adalah rasio keuangan model CAMEL (13 rasio), besaran (size) bank yang diukur dengan log, assets dan variabel dummy (kredit lancar dan manajemen). Hasil penelitian ini menunjukan bahwa secara keseluruhan tingkat prediksi variabel-variabel yang digunakan dalam penelitian ini tinggi (lebih dari 50\% sebagai cutoff value-nya). Tetapi jika dilihat dari tipe kesalahan yang terjadi tampak bahwa kekuatan prediksi untuk bank yang dilikuidasi 0\% karena dari sampel bank yang dilikuidasi, semua diprediksikan tidak dilikuidasi.

Thomson (1991) dalam Mahfoedz (1999) menguji manfaat rasio keuangan dalam memprediksi kebangkrutan perusahaan bank. Dengan menggunakan logit regression untuk menganalisis sample sebanyak 1.735 perusahaan tidak bangkrut dan 770 perusahaan bangkrut selama periode 1984 sampai dengan 1989. Thomson menyimpulkan bahwa kemungkinan perusahaan bank akan bangkrut adalah fungsi dari variable yang berkaitan dengan solvency, termasuk rasio CAMEL (Capital Asset Managemen Earnings, Liquidity) yang dimiliki.

Variabel penelitian yang digunakan adalah $\mathrm{Z}$ sebagai variabel dependen sedangkan variabel independent yang digunakan terdiri dari rasio modal kerja terhadap total aktiva, rasio laba ditahan terhadap total aktiva, rasio sebelum bunga dan pajak terhadap total aktiva (ROI), rasio modal sendiri terhadap total hutang, rasio penjualan terhadap total aktiva. Hasil analisis terhadap data keuangan masing-masing bank tersebut berdasarkan analisis diskriminan Z-Altman dapat diketahui tingkat kebangkrutan industri perbankan secara nyata dengan $\alpha=0,05$ atau 5\% sampai dengan $\alpha=0,10$ atau $10 \%$. Kemudian untuk mengetahui pengaruh dari loan to debt ratio, debt to total asset dan spread terhadap Z-score, kesimpulan yang dapat diambil dari hasil pengolahan data masing-masing variable tersebut melalui proses regresi linier berganda pada SPSS release 10,0 dapat diketahui bahwa masing-masing variable loan to debt ratio, debt to total asset dan spread mempunyai pengaruh terhadap $Z$ score baik secara parsial maupun simultan.

Fachrudin (2008) mengemukakan, kreditur, calon kreditur, investor dan calon investor sangat memerlukan informasi mengenai kinerja suatu bank untuk mengambil keputusan, apakah akan tetap sebagai kreditur, menjadi kreditur, tetap sebagai investor, menjadi investor atau tidak. Informasi yang diperlukan terutama informasi keuangan yang didapat dari laporan keuangan. Laporan keuangan tidak selalu tersedia, biasanya secara berkala. Disamping itu, tidak semua orang dapat memahami laporan keuangan secara memadai. Untuk itu ada beberapa indikasi bahwa suatu bank akan bangkrut, dilikuidasi atau ditutup. Indikasi-indikasi tersebut adalah sebagi berikut:

Tingkat bunga deposito dan tabungan yang jauh di atas rata-rata. Tingkat bunga dijadikan alat penarik dana pihak ketiga. Dana pihak ketiga di dapat bukan dari tingkat bunga yang tinggi, tetapi dari pelayanan/service yang memuaskan dan keamanan dana yang disimpan pada suatu bank.

Tingkat bunga kredit yang tinggi. Ini terpaksa dilakukan oleh bank yang bersangkutan untuk menutupi beban bunga yang diberikan kepada deposan dan penabung serta beban-beban lain. Para debitur umumnya tidak menghendaki bunga yang tinggi, kecuali jika dengan syarat-syarat yang longgar. Jika ini terjadi, cepat atau lambat, bank tersebut telah menukar sebagian aset lancarnya dengan aset tetap. 
Kurang efisien dalam mengelola aset perusahaan (bank), artinya dengan jumlah aset tertentu diperoleh hasil atau laba yang lebih sedikit jika dibandingkan dengan bank lain. Kekurangefisienan tersebut salah satunya adalah beban bunga yang tinggi. Ini disebabkan oleh pemberian tingkat bunga deposito dan tabungan yang tinggi. Kekurangefisienan lainnya dapat diketahui dengan melihat dan mempelajari laporan keuangan bank yang bersangkutan.

Manajemen bank yang kreatifinovatif selalu berusaha menciptakan berbagai produk layanan bank yang prospektif dan menguntungkan tanpa mengabaikan prinsip asset libiatlity manajemen (ALMA), yaitu menyelaraskan antara profitabilitas dan resiko.

Pelopor studi profile analysis adalah Fitz Patrick, 1932; Winakor dan Smith, 1935; dan Mervin, 1942 (Beaver, 1966), sedangkan pelopor studi prediction distress analysis adalah Beaver (1966) untuk univariate model dan Altman (1968) untuk multivariate model. Secara historis studi tentang kepailitan usaha tidak bisa dipisahkan dengan keberadaan studi profile analysis dan prediction distress analysis. Pada profile analysis ditunjukan bahwa terdapat perbedaan yang jelas antara rasio-rasio keuangan perusahaan yang pailit dan yang tidak pailit. Adapun prediction distress analysis lebih menekankan pada ramal informasi laporan keuangan tentang satu hal penting, misalnya kepailitan usaha. Hasil seluruh studi tersebut berdasarkan pada nilai dan rata-rata rasio keuangan perusahaan (profile analysis) dan sejauh mana dispersinya (prediction distress analysis) untuk beberapa waktu sebelum pailit.

Newton (1975:38) dalam Siti Rodliyah mengemukakan bahwa cara yang dapat ditempuh perusahaan untuk menganalisis kondisi keuangan perusahaan setelah memperoleh tandatanda kebangkrutan adalah analisis evaluasi kebangkrutan baik melalui metode internal maupun eksternal. Analisis eksternal dilakukan atas data yang bersumber dari luar perusahaan seperti laporan perdagangan, statistik maupun indikator ekonomi yang dikeluarkan oleh pemerintah maupun swasta.

Analisis internal dilakukan melalui antara lain: analisis strategi perusahaan dimana strategi ini menfokuskan pada persaingan yang dihadapi perusahaan, struktur biaya relatif terhadap pesaing, kemampuan perusahaan dalam mengendalikan biaya, kualitas perusahaan lainnya. Pada umumnya analisis internal yang banyak digunakan adalah analisis terhadap laporan keuangan perusahaan yaitu melalui analisis trend untuk beberapa tahun buku/periode dan analisis rasio finansial.

Dengan mempelajari trend beberapa periode dan kegiatan-kegiatan usaha perusahaan untuk beberapa tahun terakhir dihadapkan ada gambaran perkembangan, fluktuasi/kemunduran. Informasi berharga tersebut dapat menyangkut posisi keuangan dan kegiatan operasional perusahaan (laba/rugi) dari perusahaan yang bersangkutan. Suatu perusahaan diprediksikan bangkrut apabila hasil analisis trend terhadap posisi keuangan menunjukan kecendrungan menurunnya posisi kas pada bank, modal kerja dan over investment pada aktiva lancar.

Rasio Likuiditas, Rasio ini digunakan untuk mengukur kemampuan perusahaan menyelesaikan hutang/kewajibannya jatuh tempo segera dengan menggunakan aktiva lancar. Biasanya rasio yang digunakan adalah current ratio, quick ratio, cash ratio, dan net working capital. 
Rasio Leverage, Rasio ini digunakan untuk mengukur seberapa jauh/besar perusahaan dibiayai oleh hutang. Rasio leverage yang biasanya digunakan adalah debt total asset ratio, total debt to equty ratio, long term to equty ratio.

Rasio Aktivitas, Rasio ini digunakan untuk mengukur seberapa besar efektifitas perusahaan dalam memanfaatkan sumber-sumber dana perusahaan beberapa rasio yang dipergunakan adalah total asset turn over ratio, receivable turn over ratio, inventory turn over ratio, dan average collection periode.

Rasio Profitabilitas, Rasio ini memberikan gambaran tentang kemampuan suatu perusahaan untuk menghasilkan keuntungan, beberapa rasio yang sering digunakan adalah gross profit, net profit margin, rate of return on total asset.
Berdasarkan kerangka konseptual diatas dijelaskan bahwa dalam penelitian ini akan menganalisis tingkat kebangkrutan suatu perusahaan yang Go-Public di BEI dengan menggunakan metode Altman, sebelum melakukan analisis tersebut kita akan mencari indikator yang terdapat dalam analisis tersebut yaitu rasio modal kerja terhadap total aktiva $\left(x_{1}\right)$, rasio laba terhadap total aktiva $\left(x_{2}\right)$, rasio laba sebelum bunga dan pajak terhadap total aktiva $\left(x_{3}\right)$, rasio modal sendiri terhadap total hutang $\left(x_{4}\right)$, rasio penjualan terhadap total aktiva $\left(x_{5}\right)$. Dari lima indikator tersebut akan dimasukkan dalam rumus analisis Altman yang nantinya akan dapat diketahui kondisi perusahaan dalam arti dari perusahaan tersebut apakah dalam kondisi tidak bangkrut (aman), diambang bangkrut atau bangkrut.

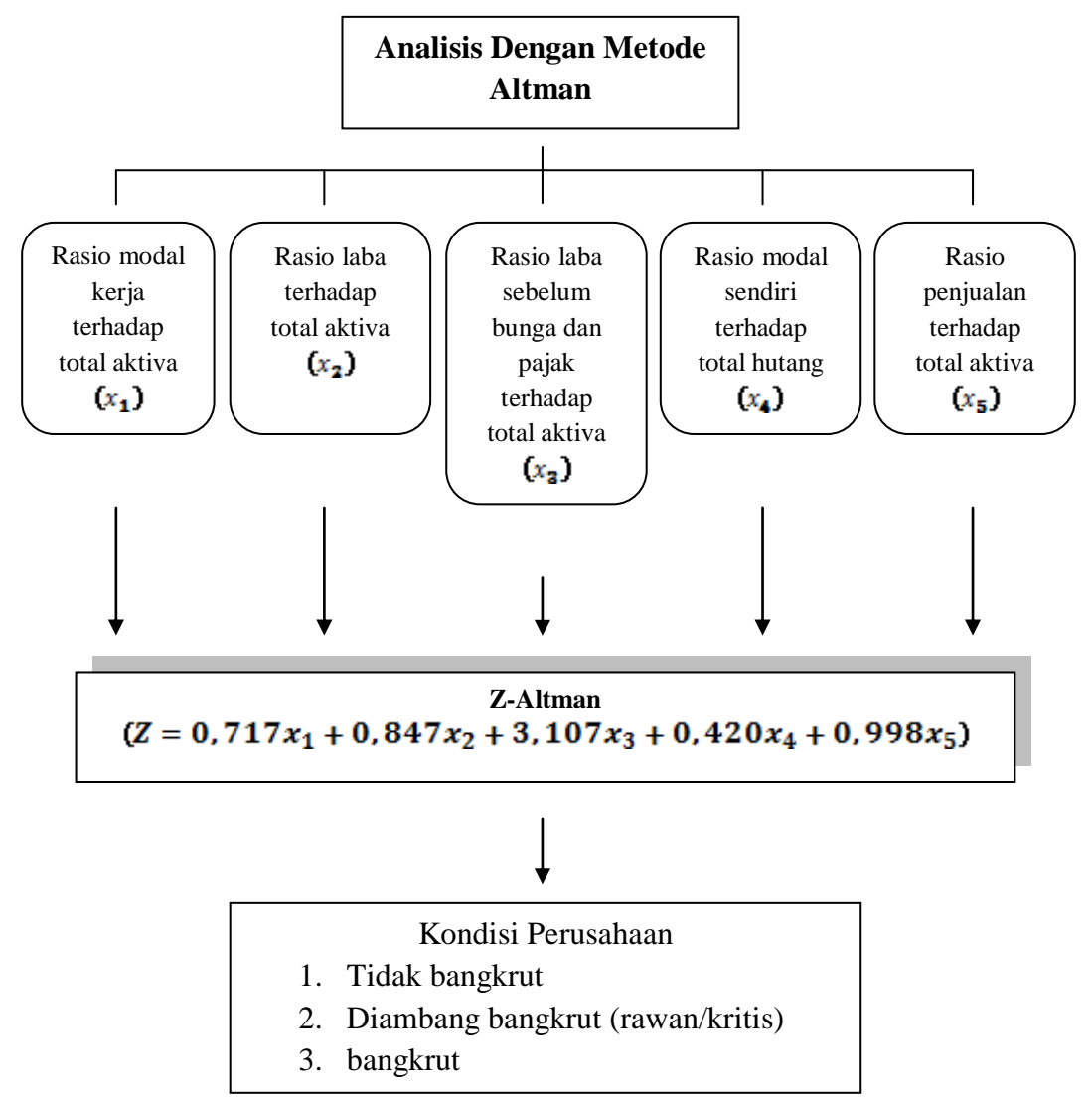

Gambar 1. Kerangka Konseptual 


\section{METODE PENELITIAN}

Untuk mendapatkan hasil penelitian diperoleh teknik yang sistematis sehingga menghasilkan penelitian yang baik pula. Maka data yang sudah diperoleh dan diolah kemudian dianalisis diskriminan ZAltman. Formulasi terbaru dari Altman (1984) adalah analisis diskriminan ZAltman yaitu:

$$
\begin{aligned}
& Z=0,717 x_{1}+0,847 x_{2}+3,107 x_{3}+0,420 x_{4}+0,998 x_{5} \\
& \text { Dimana: } \\
& Z=\text { Score Diskriminan Altman } \\
& \text { WCTA }\left(x_{1}\right)=\frac{\text { Modal Kerja }}{\text { Total Aktive }} \\
& \operatorname{RETA}\left(x_{2}\right)=\frac{\text { Laba Ditahan }}{\text { Total Aktiva }} \\
& \operatorname{ROI}\left(x_{3}\right)=\frac{\text { Laba sebelum Pajak }}{\text { Total Aktiva }} \\
& \operatorname{ETD}\left(x_{4}\right)=\frac{\text { Nilai Pasar Equitas }}{\text { Nilai Buku Hutang }} \\
& \text { STA }\left(x_{5}\right)=\frac{\text { Penjualan }}{\text { Total Aktiva }}
\end{aligned}
$$

Dengan formula tersebut akan diketahui score-score yang menunjukkan posisi perusahaan dengan kriteriakriteria yang dikemukakan oleh Altman. Dengan $\mathrm{Z}$ score dapat diketahui kondisi bangkrut, rawan atau sehat, dengan kriteria sebagai berikut 1) Untuk nilai ZScore lebih kecil dari 1,20, berarti perusahaan potensial kebangkrutan. 2)Untuk nilai Z-Score antara 1,20 sampai 2,90 maka perusahaan mengalami kondisi rawan. Perusahaan mengalami kondisi keuangan yang harus ditangani dengan penanganan menejemen yang tepat. 3)Untuk nilai ZScore lebih besar dari 2,90, memberikan penilaian bahwa perusahaan berada dalam keadaan yang sangat sehat sehingga kemungkinan kebangkrutan sangat kecil terjadi.

\section{PEMBAHASAN}

Tujuan dari perhitungan Z-score adalah untuk mengingatkan akan masalah keuangan yang mungkin membutuhkan perhatian serius dan memberikan petunjuk-petunjuk yang berguna untuk menghindari kesulitan keuangan di masa depan. Berikut ini akan dideskripsikan pembahasan hasil penelitian pada 8 perusahaan Perbankan pada Periode 2007-2008 sesuai dengan tahapan analisis data untuk model Altman (Z-Score).

$$
\begin{aligned}
Z_{2007}= & 0,717 x_{1}+0,847 x_{2}+3,107 x_{3}+0,42 x_{4}+0,998 x_{5} \\
= & 0,717(0.0878)+0,847(0.0279)+3,107(0.0198)+0,42(0,0219) \\
& +0,998(0,0401) \\
= & 0.0630+0,0236+0,0617+0,0092+0,0400 \\
= & 0,1974 \\
Z_{2008}= & 0,717 x_{1}+0,847 x_{2}+3,107 x_{3}+0,42 x_{4}+0,998 x_{5} \\
= & 0,717(0.0705)+0,847(0,0368)+3,107(0,0225)+0,42(0,0246) \\
& +0,998(0,0426) \\
= & 0.0505+0,0311+0,0699+0,0103+0,0426 \\
= & 0.2045
\end{aligned}
$$

Bank Mandiri, Kondisi keuangan Bank Mandiri termasuk dalam kondisi "Potensial Bangkrut". Hal ini terlihat pada nilai Z-Score Bank Mandiri pada tahun 2007 sebesar 0.1974 dan 2008 sebesar 0.2045. Bila dicermati, nilai ZScore pada tahun 2008 lebih tinggi dari pada nilai Z-Score tahun 2007 yang disebabkan oleh hasil harga saham yang tinggi. Di sisi lain, Bank Mandiri mampu memaksimalkan capaian EBIT, sehingga pada nilai variabel X4 tinggi pada tahun 2008. Kinerja keuangan Bank Mandiri mampu meningkatkan nilai Z-Score tahun 2008 walaupun nilainya tidak mencapai titik cut-off yang diharapkan, dengan demikian Bank Mandiri lebih produktif pada tahun 2008 dibandingkan tahun 2007.

Bank Rakyat Indonesia, Hasil analisis model Altman berkaitan dengan kondisi keuangan Bank Rakyat Indonesia pada tahun 2007-2008, kondisi keuangan Bank Rakyat Indonesia termasuk dalam kondisi "Potensial Bangkrut". Hal ini terlihat pada nilai ZScore Bank Rakyat Indonesia pada tahun 2007 sebesar 0.3385 dan 2008 sebesar 0.3130. Pada Bank Rakyat Indonesia nilai Z-Score tertinggi terjadi pada tahun 
2007, hal ini juga menunjukan kinerja keuangannya menurun pada tahun 2008. Bila dicermati, tingginya nilai Z-Score pada tahun 2007 disebabkan oleh kinerja keuangan dalam meningkatkan pendapatan dan harga saham yang lebih baik daripada tahun 2008. Hal ini juga membuat nilai EBIT dan pendapatan bersih Bank Rakyat Indonesia pada tahun 2007 lebih tinggi dari pada tahun 2008, sehingga nilai X3 dan X4 pada tahun 2007 juga tinggi.

Bank Central Asia, Hasil analisis model Altman berkaitan dengan kondisi keuangan Bank Central Asia pada tahun 2007-2008, kondisi keuangan Bank Rakyat Indonesia termasuk dalam kondisi "Potensial Bangkrut". Hal ini terlihat pada nilai Z-Score pada tahun 2007 sebesar 0.2282 dan 2008 sebesar 0.2820. Dari hasil tabel analisis diatas dapat disimpulkan bahwa Bank Central Asia mampu meningkatkan kinerja keuangannya pada tahun 2008, terlihat dari nilai Z-Score yang lebih tinggi pada tahun 2008 walaupun nilai Z-Score pada tahun 2008 tidak dapat mencapai titik cut-off yang diharapkan. Dengan demikian Bank Central Asia pada tahun 2008 mampu menunjukan produktifitas perusahaan dengan kinerja keuangan yang lebih baik pada tahun 2008, hal ini juga ditunjukan oleh hasil nilai variabelvariabel yang tinggi pada tahun 2007 daripada 2008.

Bank Negara Indonesia, Hasil analisis model Altman berkaitan dengan kondisi keuangan Bank Negara Indonesia pada tahun 2007-2008, kondisi keuangan Bank Negara Indonesia termasuk dalam kondisi "Potensial Bangkrut". Hal ini terlihat pada nilai ZScore pada tahun 2007 sebesar 0.1380 dan tahun 2008 sebesar 0.1364. Nilai ZScore pada tahun 2008 menunjukan penurunan dengan selisih yang tidak signifikan. Pada sisi lain, Bank Negara Indonesia menunjukan kinerja keuangan yang cukup stabil walaupun nilai ZScore pada hasil analisis di atas tidak seperti yang diharapkan. Bila dicermati, penurunan nilai Z-Score dari tahun 2008 disebabkan oleh turunnya kemampuan kinerja keuangan Bank Negara Indonesia dalam meningkatkan modal kerja, sehingga nilai variabel $\mathrm{X} 1$ mengalami penurunan pada tahun 2008 .

Bank Danamon, Hasil analisis model Altman berkaitan dengan kondisi keuangan Bank Danamon pada tahun 2007-2008, kondisi keuangan Bank Danamon termasuk dalam kondisi "Potensial Bangkrut". Hal ini terlihat pada nilai Z-Score pada tahun 2007 sebesar 0.3376 dan tahun 2008 sebesar 0.2946. Hal ini menunjukan kinerja keuangan Bank Danamon yang lebih baik terjadi pada tahun 2007 dibandingkan tahun 2008. Pada sisi lain, Bank Danamon tidak dapat meningkatkan kinerja keuangan pada tahun 2008, sehingga nilai variabelvariabel pada tabel analisis $\mathrm{di}$ atas menunjukan nilai yang lebih rendah pada tahun 2008 dibandingkan tahun 2007.

Bank CIMB Niaga, Hasil analisis model Altman berkaitan dengan kondisi keuangan Bank CIMB Niaga (selanjutnya disebut Bank Niaga) pada tahun 2007-2008, kondisi keuangan Bank Niaga termasuk dalam kondisi "Potensial Bangkrut". Hal ini terlihat pada nilai Z-Score tahun 2007 sebesar 0.2282 dan tahun 2008 sebesar 0.1894. Hal ini juga menunjukan kinerja kinerja Bank Niaga yang kurang baik pada tahun 2008. Bila dicermati, tingginya nilai Z-Score pada tahun 2007 disebabkan oleh kemampuan Bank Niaga meningkatkan capaian EBIT, sehingga nilai variabel $\mathrm{X} 4$ lebih tinggi pada tahun 2007 dibandingkan 2008 yang perbandingannya sangat signifikan.

Bank Permata, Hasil analisis model Altman berkaitan dengan kondisi keuangan Bank Permata pada tahun 
2007-2008, kondisi keuangan Bank Permata termasuk dalam kondisi "Potensial Bangkrut". Hal ini terlihat pada nilai Z-Score pada tahun tahun 2007 sebesar 0.2544 dan tahun 2008 sebesar 0.1680. Bila dicermati, nilai ZScore tertinggi terjadi pada tahun 2007, ini menunjukan kemampuan kinerja keuangan Bank Permata mengalami perununan yang signifikan pada tahun 2008. Hal ini juga didukung dengan penurunan nilai varibel-variabel keuangan yang ada pada tabel analisis di atas.

Bank Internasional Indonesia, Hasil analisis model Altman berkaitan dengan kondisi keuangan Bank Internasional Indonesia (selanjutnya disebutkan BII) pada tahun 2007-2008, kondisi keuangan BII termasuk dalam kondisi "Potensial Bangkrut". Hal ini terlihat pada nilai Z-Score pada tahun 2007 sebesar 0.1688 dan 2008 sebesar 0.1821. Bila dicermati, kinerja keuangan BII dari tahun 2007-2008 menunjukan produktifitas yang baik. BII dapat meningkatkan nilai Z-Score pada tahun 2008, tingginya nilai Z-Score pada tahun 2008 disebabkan oleh kemampuan BII dalam meningkatkan kinerja keuangan untuk mencapai EBIT dan harga saham yang tinggi. Hal ini juga membuat nilai variabel $\mathrm{X} 2$ dan $\mathrm{X} 3$ tinggi pada tahun 2008.

Berdasarkan hasil perhitungan untuk bank yang telah dijadikan sampel, terlihat bahwa semua bank dikategorikan petonsial bangkrut (nilai Z-score di bawah 1,20) baik untuk Bank Umum Nasional maupun Bank Umum Swasta. Sehingga dapat dikatakan bahwa model Z-score tidak dapat digunakan untuk memprediksi kesulitan keuangan dan kebangkrutan dalam industri perbankan Indonesia. Hal ini antara lain disebabkan sebagai berikut:

Model Z-score dari Altman dibentuk dari perusahaan manufaktur yang bangkrut dan tidak bangkrut yang memiliki karakteristik bisnis yang berbeda dengan industri perbankan.

Dalam industri perbankan, working capital bank atau merupakan selisih antara aktiva lancar dan hutang lancar bank biasanya cenderung memiliki nilai yang negatif. Sehingga apabila nilai Z-score digunakan, maka akan memiliki nilai negatif (bangkrut). Padahal working capital yang negatif dalam industri perbankan merupakan suatu hal yang biasa, karena sebagai financial intermediary dengan modal sendiri yang rata-rata di bawah $10 \%$, bank harus memiliki dana dari pihak ke3 dengan jumlah yang cukup besar (termasuk hutang lancar) sementara untuk memaksimalkan penggunaan dana tersebut bank harus menyalurkan ke dalam instrumen yang paling optimum yaitu kredit (non aktiva lancar).

Oleh karena itu, untuk melengkapi analisis Z-score dalam memprediksi kesulitan keuangan dan kebangkrutan industri perbankan Indonesia dapat digunakan suatu alat ukur yang biasa digunakan untuk mengukur tingkat kesehatan suatu bank. Alat ukur tingkat kesehatan bank tersebut dikenal sebagai CAMEL yang terdiri dari capital (CAR), aktiva (kualitas aktiva produktif), manajemen (permodalan, aktiva, umum, rentabilitas, likuiditas), earning (ROA, rasio efisiensi), dan likuiditas (rasio call money, LDR). Adanya ketentuan tingkat kesehatan bank dalam industri perbankan dimaksudkan sebagai 1) Tolok ukur bagi manajemen bank untuk menilai apakah pengelolaan bank telah dilakukan sejalan dengan asas-asas perbankan yang sehat dan sesuai dengan ketentuan-ketentuan yang berlaku; 2) Tolok ukur untuk menetapkan arah pembinaan dan pengembangan bank baik secara individual maupun perbankan secara keseluruhan. 
Namun demikian, mengingat

Surat Keputusan Bank Indonesia No. SK bahwa untuk menguk ur tingkat kesehatan suatu bank berdasarkan aspek capital, aktiva, dan manajemen tidak mungkin dilakukan oleh masyarakat (pihak luar bank), kecuali oleh bank itu sendiri dan Bank Indonesia, maka dalam tulisan ini tingkat kesehatan bank hanya akan dihitung berdasarkan aspek rentabilitas dan likuiditas. Berdasarkan DIR 30/II/KEP/DIR tanggal 4 April 1997, predikat tingkat kesehatan bank untuk aspek rentabilitas dan likuiditas dapat dilihat pada tabel dibawah

Setelah rasio dari masing-masing aspek predikat tingkat kesehatan dimasukkan, maka diperoleh tingkat kesehatan masing-masing bank seperti terlihat pada tabel 1 .

Tabel 1. Nilai dan Predikat Tingkat Kesehatan Bank Berdasarkan Surat Keputusan BI No. SK DIR 30/II/KEP/DIR 1997

\begin{tabular}{llllll}
\hline No & $\begin{array}{l}\text { Aspek } \\
\text { Kesehatan }\end{array}$ & Tidak Sehat & Kurang Sehat & Cukup Sehat & Sehat \\
\hline & Earning & & & & \\
1 & ROA & $0-<0,765 \%$ & $0,765-<0,99$ & $0,99-<1,215$ & $1,215-1,5 \%$ \\
2 & Rasio Efisien & $95,92<-100 \%$ & $94,72<-95,92$ & $93,2<-94,72$ & $92-93,2 \%$ \\
& Likuiditas & & & $19<-34$ & $1-19 \%$ \\
1 & Rasio Call & $49<-100$ & $34<-49$ & $94,75<-98,5$ & $90-94,75 \%$ \\
\hline
\end{tabular}

Tabel 2. Analisis Tingkat Kesehatan Bank Sampel Periode 2007

\begin{tabular}{|c|c|c|c|c|c|}
\hline \multirow[b]{2}{*}{ No } & \multirow[b]{2}{*}{ Nama Bank } & \multicolumn{2}{|c|}{ Earning } & \multicolumn{2}{|c|}{ Likuiditas } \\
\hline & & ROA & $\begin{array}{c}\text { Rasio } \\
\text { Efisien }\end{array}$ & $\begin{array}{c}\text { Rasio Call } \\
\text { Money }\end{array}$ & LDR \\
\hline 1 & Bank Mandiri & $\begin{array}{l}1.98 \\
\text { (sehat) }\end{array}$ & 71.44 (sehat) & 90.82 (sehat) & $\begin{array}{l}50.73 \\
\text { (sehat) }\end{array}$ \\
\hline 2 & Bank Rakyat Indonesia & $\begin{array}{l}3.82 \\
\text { (sehat) }\end{array}$ & 62.10 (sehat) & 88.69 (sehat) & $\begin{array}{l}63.96 \\
\text { (sehat) }\end{array}$ \\
\hline 3 & Bank Central Asia & $\begin{array}{l}2.94 \\
\text { (sehat) }\end{array}$ & 65.88 (sehat) & 92.42 (sehat) & $\begin{array}{l}42.66 \\
\text { (sehat) }\end{array}$ \\
\hline 4 & Bank Negara Indonesia & $\begin{array}{l}0.81 \\
\text { (kurang } \\
\text { sehat) }\end{array}$ & 79.11 (sehat) & 91.41 (sehat) & $\begin{array}{l}56.92 \\
\text { (sehat) }\end{array}$ \\
\hline 5 & Bank Danamon & $\begin{array}{l}3.71 \\
\text { (sehat) }\end{array}$ & 75.41 (sehat) & 85.91 (sehat) & $\begin{array}{l}79.88 \\
\text { (sehat) }\end{array}$ \\
\hline 6 & Bank Niaga & $\begin{array}{l}2.22 \\
\text { (sehat) }\end{array}$ & 77.66 (sehat) & 87.70 (sehat) & $\begin{array}{l}75.04 \\
\text { (sehat) }\end{array}$ \\
\hline 7 & Bank Permata & $\begin{array}{l}1.87 \\
\text { (sehat) }\end{array}$ & 76.72 (sehat) & 92.58 (sehat) & $\begin{array}{l}59.44 \\
\text { (sehat) }\end{array}$ \\
\hline 8 & $\begin{array}{l}\text { Bank Internasional } \\
\text { Indonesia }\end{array}$ & $\begin{array}{l}0.55 \text { (tidak } \\
\text { sehat) }\end{array}$ & $\begin{array}{l}96.29 \text { (tidak } \\
\text { sehat) }\end{array}$ & 89.37 (sehat) & $\begin{array}{l}72.58 \\
\text { (sehat) }\end{array}$ \\
\hline
\end{tabular}


Tabel 3. Analisis Tingkat Kesehatan Bank Sampel Periode 2008

\begin{tabular}{|c|c|c|c|c|c|}
\hline \multirow[b]{2}{*}{ No } & \multirow[b]{2}{*}{ Nama Bank } & \multicolumn{2}{|c|}{ Earning } & \multicolumn{2}{|c|}{ Likuiditas } \\
\hline & & ROA & Rasio Efisien & $\begin{array}{c}\text { Rasio Call } \\
\text { Money }\end{array}$ & LDR \\
\hline 1 & Bank Mandiri & 2.25 (sehat) & 67.00 (sehat) & 92.62 (sehat) & $\begin{array}{l}56.25 \\
\text { (sehat) }\end{array}$ \\
\hline 2 & Bank Rakyat Indonesia & 3.59 (sehat) & 63.47 (sehat) & 91.37 (sehat) & $\begin{array}{l}75.53 \\
\text { (sehat) }\end{array}$ \\
\hline 3 & Bank Central Asia & 3.14 (sehat) & 59.41 (sehat) & 91.93 (sehat) & $\begin{array}{l}52.51 \\
\text { (sehat) }\end{array}$ \\
\hline 4 & Bank Negara Indonesia & $\begin{array}{l}0.96 \text { (kurang } \\
\text { sehat sehat) }\end{array}$ & 69.11 (sehat) & 93.84 (sehat) & $\begin{array}{l}65.18 \\
\text { (sehat) }\end{array}$ \\
\hline 5 & Bank Danamon & 2.50 (sehat) & 85.68 (sehat) & 90.38 (sehat) & $\begin{array}{l}84.06 \\
\text { (sehat) }\end{array}$ \\
\hline 6 & Bank Niaga & $\begin{array}{l}1.05 \\
\text { (cukup } \\
\text { sehat) }\end{array}$ & 88.47 (sehat) & 87.94 (sehat) & $\begin{array}{l}84.65 \\
\text { (sehat) }\end{array}$ \\
\hline 7 & Bank Permata & 1.40 (sehat) & 82.09 (sehat) & 95.67 (sehat) & $\begin{array}{l}56.82 \\
\text { (sehat) }\end{array}$ \\
\hline 8 & $\begin{array}{l}\text { Bank Internasional } \\
\text { Indonesia }\end{array}$ & $\begin{array}{l}1.15 \text { (cukup } \\
\text { sehat) }\end{array}$ & $\begin{array}{l}94.30 \\
\text { (cukup sehat) }\end{array}$ & 91.13 (sehat) & $\begin{array}{l}79.87 \\
\text { (sehat) }\end{array}$ \\
\hline
\end{tabular}

Berdasarkan tabel di atas, dengan melihat hanya dari sudut pandang earning dan likuiditas ternyata bankbank yang dijadikan sampel kriteria sehat. Apabila kita hubungkan kembali dengan nilai $\mathrm{Z}$, ternyata bank -bank yang tidak memenuhi kriteria sehat tersebut juga memiliki nilai $\mathrm{Z}$ yang relatif lebih kecil. Bank yang tidak sehat tentunya juga mempunyai risiko yang lebih tinggi untuk mengalami kesulitan keuangan dan bahkan bangkrut, demikian juga dengan bank-bank yang memiliki nilai $\mathrm{Z}$ yang rendah. Sehingga dapat disimpulkan bahwa penggunaan model Z-score untuk industri perbankan akan memberikan manfaat yang lebih baik apabila analisis tersebut didukung oleh CAMEL (lebih baik jika ke-5 aspek penilaian dapat dilakukan) dan analisis lain yang bersifat non finansial kualitatif dan kuantitatif.

Model Altman tidak sesuai diterapkan untuk memprediksi kebangkrutan sektor perbankan di Indonesia. Hal ini terbukti dari prediksi Altman yang menyatakan potensial bangkrut untuk seluruh sampel penelitian, sebaliknya, menurut rating
Bank Indonesia (www.bi,go.id) bank sampel memiliki aset terbesar hingga akhir periode 2008.

Dalam penerapan Model Altman tidak bisa serta merta di terapkan, tetapi harus mempertimbangkan beberapa hal 1) Model Altman ditemukan sebagai sarana untuk memprediksi kebangkrutan perusahaan sektor manufaktur di Amerika Serikat. 2) Perilaku perusahaan manufaktur berbeda dengan perilaku perusahaan perbankan dalam hal a) Sektor perbankan merupakan Administered Industry yaitu industri yang selalu di awasi pemerintah, sehingga penilaian kinerja keuangan memiliki aturan tersendiri di tiap-tiap Negara. b)Sektor perbankan bukanlah perusahaan yang berdiri sendiri (BUMN maupun Swasta), tetapi mendapat dukungan dari Pemerintah (Lembaga Penjamin Simpanan) karena bank merupakan perusahaan publik yang berazas kepercayaan yang berpengaruh luas terhadap masyarakat dan perekonomian Negara.c)Rasio Working Capital (Modal Kerja/Total Aktiva) yang bernilai rendah atau negative merupakan hal yang biasa bagi sektor 
perbankan, tetapi bagi sektor manufaktur hal ini jarang terjadi.d)Penerapan Model Altman pada perusahaan perbankan perlu disertai atau didampingi oleh penerapan model penilaian kinerja keuangan lainnya, yaitu bersumber dari pihak yang berwenang (Pemerintah atau Bank Sentral) dan sesuai dengan standart yang ada di Negara yang bersangkutan.

\section{PENUTUP}

Berdasarkan hasil penelitian yang telah dilakukan pada perusahaan perbankan yang Go-Public yang terdaftar di Bursa Efek Indonesia (PT.BEI) periode 2007-2008, maka dapat diambil kesimpulan Hasil perhitungan Z-score untuk melakukan prediksi kesulitan keuangan dan kebangkrutan atas laporan keuangan selama 2 tahun dari tahun 2007-2008 terhadap 8 bank Go-Public yang termasuk dalam daftar 10 bank dengan aset terbesar sepanjang periode 2008 yang juga terdaftar di Bursa Efek Indonesia (PT.BEI), ternyata semua bank tersebut menghasilkan Z-score yang lebih kecil dari 1,20 sehingga diklasifikasikan dan diprediksikan sebagai bank yang potensial kebangkrutan. Hal tersebut seharusnya tidak demikian terutama untuk bankbank yang dijadikan sampel masih beroperasi atau masih menjalankan usahanya.

Model Z-score dari Altman tidak dapat diterapkan pada dunia perbankan Indonesia, karena menghasilkan hal yang bertolak belakang terutama untuk bankbank yang dapat beroperasi tanpa rekapitalisasi. Hal ini disebabkan karena model Z-score dibentuk dari studi empirik terhadap industri manufaktur yang tentunya sangat berbeda dengan industri perbankan. Dalam industri perbankan misalnya terdapat ketentuan minimum sebesar 4-12\% x ATMR yang mencakup aktiva yang tercantum dalam neraca maupun off balance sheet. Dalam menghitung ATMR terhadap masingmasing aktiva diberikan bobot sesuai dengan risiko yang didasarkan pada kadar risiko yang tergantung pada aktiva itu sendiri atau bobot risiko yang didasarkan pada golongan nasabah dan sifat agunan. Hal inilah yang tidak diperhitungkan dalam model Z-score dari Altman.

Perlu penelitian lebih lanjut mengenai model Z-score untuk memprediksi kesulitan keuangan dan kebangkrutan dalam industri perbankan dengan meneliti kembali variabelvariabel yang memiliki potensi untuk memberikan prediksi yang paling tepat mengenai bangkrutnya suatu bank. Variabel-variabel CAMEL antara lain dapat diteliti lebih lanjut sebagai variabel yang berpotensi dalam memprediksi kebangkrutan bank

\section{DAFTAR PUSTAKA}

Altman, E., G.R. Haldeman And P. Narayanan, 1977, Zeta Analysis : A New Model To Identify Bankruptcy Risk Of Corporation, Journal Of Banking And Finance, Volume 1, pp.29-54., 2001.

Brigham dan Gapenski, M.D, Hadad, 2004, Model Prediksi Kepailitan Bank Umum di Indonesia, Direktorat Penelitian dan Pengaturan Perbankan, BI.

Dian Suryandari, 2006, Kinerja Keuangan Perbankan Nasional Indonesia Sebelum, Selama dan Pada Pasca Krisis Moneter, Skripsi Universitas Islam Indonesia.

Fachrudin, 2008, Beberapa Indikasi Bank Likuidasi, Pidato 
Pengukuhan Jabatan Guru Besar Tetap, Universitas Sumatra Utara. Indriantoro dan Soepomo, 1999, Metode Penelitian Bisnis, Untuk Akuntansi dan Manajemen, Yogyakarta: BPFE.

Indonesian Capital Market Directory, Laporan Keuangan, tahun 2004, 2005, 2006, 2007 dan 2008, BEI, Maland.

J. Fred Weston \& Thomas E. Copelond, 1995, Manajemen Keuangan, Jilid I, Edisi Kesembilan, Binarupa Aksara, Jakarta.

J. Fred Weston \& Thomas E. Copelond, 1997, Manajemen Keuangan, Jilid II, Edisi Kesembilan, Binarupa Aksara, Jakarta.

Jauch, Lawrence R. and Glueck William F, 1994, Kebijakan Perusahaan dan Manajemen Strategi, Edisi II, Jakarta: Erlangga.

Krugman, R.,P, 1999, Ekonomi Internasional, Penerbit PAU-FE, Universitas Indonesia dan Harpercollins Publisher.

Mahfoedz, M., 1999, Profil Kinerja Finansial Perusahaan Yang Gopublik Di Pasar Modal ASEAN, Jurnal Ekonomi Bisnis Indonesia 14,pp. 56-72.

Martin, et.al., 1995, Dasar-Dasar Manajemen Keuangan, Edisi Kelima, Jakarta: PT. Raja Grafindo Persada.

Th. Niken Setyorini dan A. Yanti Ardiati, 2006, Pengaruh Potensi Perusahaan Publik, Universitas Atma Jaya Yogyakarta.
Siti Rodliyah, Newton, 1975, Penerapan Analisis Diskriminan Altman Untuk Memprediksi Tingkat Kebangkrutan, Alumnus Program Studi Akuntansi UMM.

Sugiono, 2001, Statistik Nonparametik Untuk Penelitian, Cetakan Kedua, ALFABETA, Bandung.

Surat Keputusan Bank Indonesia No.SK DIR 30/II/KEP/DIR tanggal 4 April 1997.

Weston dan Copeland, 1994, Manajemen Keuangan, Jilid 1 Edisi Kesembilan, Jakarta: Binarupa Aksara.

Wilopo, Luciana Soica Almilia dan Winny Herdinigtyas, Analisis Rasio CAMEL terhadap Prediksi Kondisi Bermasalah Pada Lembaga Perbankan, Jurnal Ekonomi, STIE PERBANAS Surabaya.

Undang-Undang No.10 Tahun 1998 tentang perbankan, Bank Indonesia, Jakarta. 
